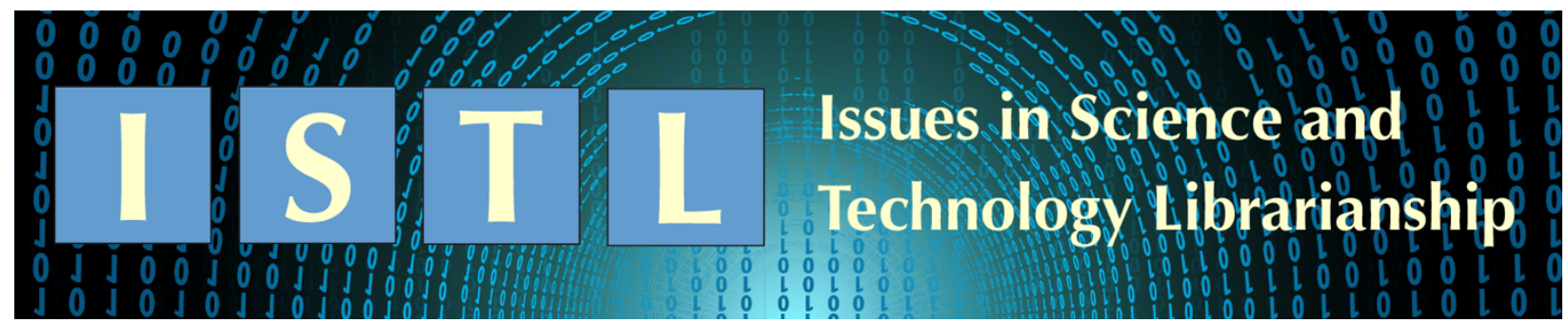

\title{
Viewpoints
}

\section{Virtual Learning and the Role of Liaison Librarians in STEM Academic Programs}

\author{
Retno Sayekti \\ Head of the Department of Library Science \\ Universitas Islam Negeri Sumatera Utara \\ Medan, Indonesia \\ retnosayekti69@uinsu.ac.id
}

\begin{abstract}
This viewpoint aims to present the important role of liaison librarians and their relationship with teaching staff in STEM academic programs. The work provides a detailed explanation of the role of the four components of liaison librarians in the STEM higher education environment, each with the best practice proposed. The closing remarks emphasize the importance of liaison librarians, which are absent in academic libraries in most nations of the world, but in this case especially in Indonesia.
\end{abstract}

\section{Introduction}

This essay was motivated by Dr. Shirin Maryam Jamarani's presentation entitled Online Learning in World Religions, during the Development of Library Management System (DELSMA) training activity organized by the Indonesian Ministry of Religious Affairs at the University of Queensland (UQ), Brisbane, Australia from 15th to 23rd October 2015.

The University of Queensland is one of the universities in Australia with a strong STEM emphasis (https://www.queenslandstem.edu.au/) where subjects in the fields of science, technology, engineering, and mathematics are offered to students to prepare them for real-world future challenges. Universities of this type offer opportunities for students to develop STEM knowledge and skills to prepare them for the future.

The University of Queensland used an integrated electronic learning system in the learning process called Blackboard. Dr. Jamarani stated that lecturers, students, and librarians use the Blackboard-based e-learning system in the learning process, be it in the classrooms or in the library. This indicates that a system is built to be used by various campus academic elements simultaneously and in accordance with their respective main tasks and roles and sustained by their contribution. The Blackboard e-learning system at the UQ was also integrated with a 
recording machine used to teach by lecturers in class (Figure 1). The machine records students' learning activities in the form of video or audio and uploads it directly to the e-learning system.

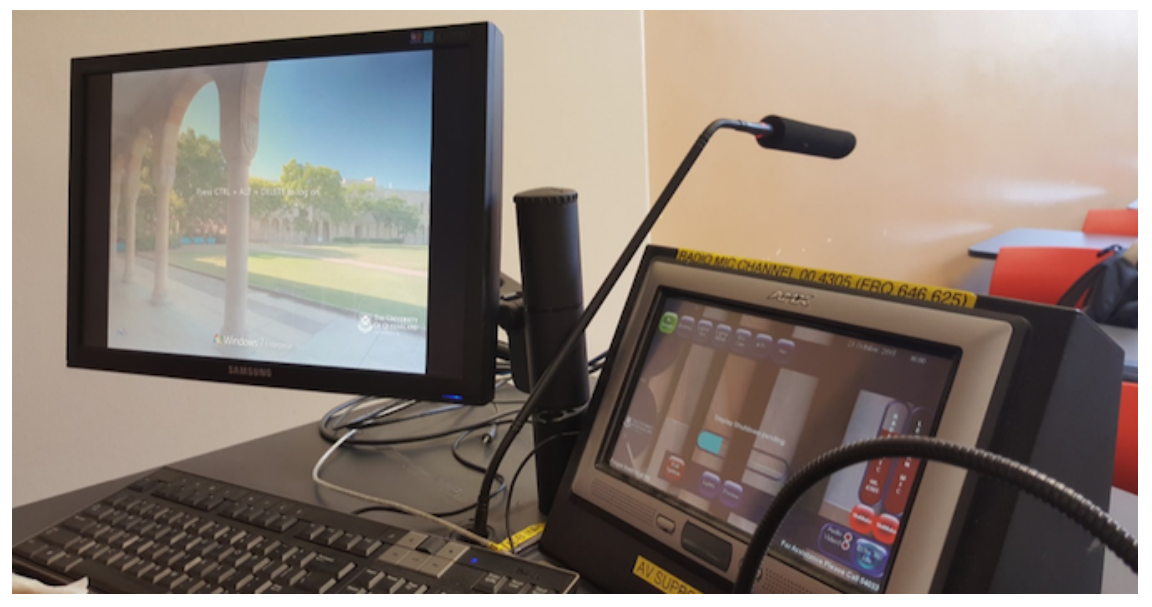

Figure 1: Recording machine for learning activities by lecturers in the class

This essay is also motivated by my interest to share my personal experience in developing and utilizing electronic learning as a learning medium (http://elearning.uinsu.ac.id) at the Universitas Islam Negeri Sumatera Utara Medan (State Islamic University of North Sumatra Medan) as one of Indonesia's STEM universities with departments in health science, technology and mathematics.

Dr. Jamarani's presentation provided the idea for designing a career development training program for lecturers that can be applied at our university. Such a program aims to train lecturers on the use of electronic-based learning media (e-learning) and information literacy skills in writing scientific papers. Generally, writing scientific papers is an important task for students in all fields of the sciences, engineering, technology, and medical sciences (Kim et al. 2020). Students are expected to have skills in identifying, searching, and using information ethically. This led to the formation of information literacy standards of the Association of College and Research Libraries: ACRL Framework for Information Literacy for Higher Education.

This viewpoint article describes how librarians play essential roles and contribute to maximizing the use of e-learning information technology tools (Ciccone \& Hounslow 2019). Furthermore, the role of liaison librarian is a concept to be developed in UQ library, Indonesia's academic libraries, and hopefully in other countries.

This project was also carried out due to my interest in developing ideas for the use of information technology to increase student independence in learning to achieve efficiency and effectiveness. Librarians played a significant role in this study by contributing immensely to improving students' and lecturers' intelligence and academic skills in the field of research and learning. It is believed that upon the development and implementation of this system in university libraries, their image, which should be as important as the teaching faculty, will be increased. I also introduce the concept of the liaison librarian and its associated skills.

\section{Understanding Virtual (Electronic) Learning}

Virtual learning is an online learning media that uses information and communication technology networks and computers to cover all learning activities (Naidu 2006; Rossen \& Hartley 2001). In many universities, e-learning is a complement to face-to-face learning, better known as hybrid 
learning. This teaching method is considered a very important part of teaching strategy, especially in delivering materials online, due to its flexibility and support (Muhsen et al. 2013). An empirical research article by Mehta et al. (2019) also demonstrated that the adoption of elearning in teaching has an influence of self-enhancement values via social influence, price value and performance expectancy. Linawati et al. (2012) revealed that technology, content development and quality of services are the most important factors to deliver an e-learning project.

\section{Liaison Librarians and Their Roles}

Some studies suggest that the term 'liaison librarian' applies only to college libraries because their main role is to bridge academic relationships between lecturers, students, and information sources in supporting research and learning activities (Amudhavalli 2010; East 2007; Jaguszweski \& Williams 2013; Lyman 2001; Torabi 2010). Haglund and Herron (2009) stated that librarians also play consultant roles for lecturers and students in carrying out academic assignments.

Cotta-Schønberg (2007) stated that a liaison librarian needs to have proficiency in information literacy. Meanwhile, according to East (2007) and Lund (2010), academic librarians' main task is to provide guidance and education, similar to the methods used by teachers or lecturers to guide students through the complex process of finding and evaluating information. Lund (2010) reported that a liaison librarian also provides research assistance services to library users in searching for information related to specific subjects. The guidance also includes research methodology, which is specifically given to post-level students.

Liaison librarian participation and involvement in developing course materials start from syllabus compilation to lecture delivery strategies. Furthermore, they collaborate with professors in specific fields, such as STEM subjects, to create web portals (Paris 2007). However, what needs to be underlined is that the form of cooperation or collaboration does not have to be formal. This is because informal cooperation or relationships have also proven to be more effective in developing information literacy (IL) skills and are mutually beneficial for collaborating parties. Libraries and librarians can also deepen and broaden their knowledge in the research process (Daland 2013; Olsson \& Bosch 2016).

Therefore, an information literacy librarian needs to also understand the latest learning technology in the form of electronic learning (e-learning) as implemented at the University of Queensland, Australia. Liaison librarians in this current Information and Communication Technologies (ICT) era also play a role as a sci-tech librarian, with mastery of knowledge in the field of science and technology important and capable of supporting successful function as a liaison.

Liaison librarians for STEM departments need to develop teaching and assessment skills through conferences, workshops, team-teaching, and observing peer teaching to master the academic skills required. In terms of scientific communication, academic librarians need to develop a personal attitude to maintain accuracy and up-to-date knowledge of general trends in certain subjects, including the STEM fields. Therefore, liaison librarians need to be able to use various electronic learning tools to teach information literacy to students with the addition of knowledge in the fields of science and technology (Kuruppu 2013; Pensyl 1991). Furthermore, the skills in educating and informing lecturers, postgraduate students, and campus administration staff regarding scientific communication issues, copyright, and author rights also need to be studied and implemented. The ability to investigate and promote new pathways in the development of scientific communication, such as open access publications, institutional repositories, journal 
hosting, etc., is also important. In addition, they also need to be able to support the management of bibliographic data analytics. Therefore, liaison librarians need to possess adequate knowledge related to bibliometrics to support STEM students and lecturers in determining new ideas.

The liaison librarian is a professional librarian who plays an active role in bridging academic departments and library services to develop new ways of implementing learning support into the work processes undertaken by students. Therefore, to realize the three pillars of higher education, which includes learning, research, and community service, they need to work closely with web developers to develop content and identify ways in which learning can be improved (Jaguszweski \& Williams 2013).

\section{Conclusion}

The role of liaison librarian as a profession that bridges information resources and users, such as students and lecturers, can be divided into three categories, which are integrated into one skill for the development of learning materials, research methodology, writing scientific papers, and information technology. While playing those important roles, they can utilize an e-learning platform to ease the access of learning materials. Liaison librarians at universities with strong STEM programmatic emphases need to enrich their knowledge in the field of science and technology.

For each skill, librarians need to collaborate with various parties and other professions, such as postgraduate students, lecturers, researchers, and programmers. Furthermore, librarians can use electronic learning as a medium to develop skills in information literacy through the integration of knowledge and expertise in these three fields. In fact, they can also become consultants and assistants in the use of these media for fellow lecturers and researchers in various academic departments, particularly those in STEM departments, more especially for those unable to keep up-to-date with the use of new technology.

At the end of this process, librarians are likely to have an equal image and professionalism with the teaching faculty and researchers at universities because they have an equally important role and contribute to improving students' academic productivity and skills. Finally, this viewpoint article also differentiates the existence of modern and traditional librarianship.

\section{References}

Amudhavalli, A. 2008. Information Literacy and Higher Education Competency Standards. DESIDOC Journal of Library \& Information Technology. 28(2):48-55. DOI: $10.14429 /$ djlit.28.2.167.

Ciccone, A., \& Hounslow, L. 2019. Re-envisioning the role of academic librarians for the digital learning environment: The case of UniSA Online. Journal of University Teaching \& Learning Practice. 16(1). Available from https://ro.uow.edu.au/jutlp/vol16/iss1/11.

Cotta-Schønberg, M. 2007. The changing role of the subject specialist. LIBER Quarterly. 17(3/4). DOI: $10.18352 /$ lq.7890.

Daland, H. 2013. The Ph.D.-candidate as an information literate resource: Developing research support and information literacy skills in an informal setting. LIBER Quarterly. 23(2):134-155. DOI: $10.18352 /$ lq.9214. 
East, J.W. 2007. The future role of the academic liaison librarian: A literature review [Internet]. Brisbane (AU): University of Queensland. Available from

http://core.ac.uk/download/pdf/11882761.pdf.

Haglund, L., \& Herron, D. 2009. Reference services in Australian academic libraries are becoming more multifaceted. Evidence Based Library and Information Practice. 4(3):56-59. DOI: $10.18438 / \mathrm{B} 81905$.

Jaguszewski, J.M., \& Williams, K. 2013. New Roles for New Times: Transforming Liaison Roles in Research Libraries. Washington (DC): Association of Research Libraries. Available from https://www.arl.org/resources/new-roles-for-new-times-transforming-liaison-roles-inresearch-libraries/.

Kim, M., Franco, M., \& Seo, D. 2020. Implementing information literacy (IL) into stem writing courses: Effect of IL instruction on students' writing projects at an urban community college. Issues in Science and Technology Librarianship. 94. DOI: 10.29173/istl61.

Kuruppu, P.U. 2013. Recruitment of science and technology librarians: A review. Science \& Technology Libraries. 27(1/2):11-40. DOI: 10.1300/J122v27n01 03.

Linawati, Sukadarmika, G., \& Sasmita, G.M.A. 2012. Synchronization interfaces for improving Moodle utilization. Telkomnika. 10(1):179-188.

Lund, P. 2010. A travelling librarian: Lessons learnt from a study visit to libraries serving research-intensive universities in the USA. SCONUL Focus. 50:61-65.

Lyman, P. 2001. Information literacy. Liberal Education. 87(1):28-37.

Mehta, A., Morris, N.P., Swinnerton, B., \& Homer, M. 2019. The influence of values on elearning adoption. Computers and Education. 141:103617. DOI:

10.1016/j.compedu.2019.103617.

Muhsen, Z.F., Maaita, A., Odah, A., \& Nsour, A. 2013. Moodle and e-learning tools. International Journal of Modern Education and Computer Science. 5(6):1-8. DOI: 10.5815/ijmecs.2013.06.01.

Naidu, S. 2006. E-Learning: A Guidebook of Principles, Procedures and Practices. New Delhi (India): Commonwealth Educational Media Center for Asia. Available from http://hdl.handle.net/11599/53.

Olsson, H.H., \& Bosch, J. 2016. Collaborative innovation: A model for selecting the optimal ecosystem innovation strategy. In: Proceedings - 42nd Euromicro Conference on Software Engineering and Advanced Applications, SEAA 2016. pp.206-213. DOI: 10.1109/SEAA.2016.55.

Paris, T. 2007. Breaking the mould: How re-examining the allocation formula led to the creation of a dynamic role for the university's librarians. Partnership: The Canadian Journal of Library and Information Practice and Research. 2(2). DOI: 10.21083/partnership.v2i2.302.

Pensyl, M. 1991. Emerging roles for academic librarians in the technology transfer process. Science \& Technology Libraries. 11(2):29-38. DOI: 10.1300/J122v11n02 03. 
Rossen, E.M., \& Hartley, D. 2001. Basics of E-learning. Alexandria (VA): ASTD Press.

Torabi, N. 2010. Library school curricula in the US should address liaison responsibilities for students interested in academic librarianship. Evidence Based Library and Information Practice. 5(2):100-102. DOI: 10.18438/B8H326.

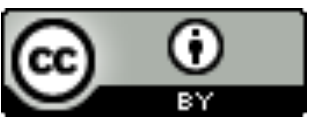

This work is licensed under a Creative Commons Attribution 4.0 International License. 